\title{
INCREASED ABLATION AT THE MARGIN OF THE GREENLAND ICE SHEET UNDER A GREENHOUSE-EFFECT CLIMATE
}

\author{
by
}

Roger J. Braithwaite and Ole B. Olesen

(Grønlands Geologiske Undersøgelse, DK-1350 København K, Denmark)

\section{ABSTRACT}

Increased ablation under a greenhouse-effect climate is calculated by an energy-balance model for two sites at the margin of the Greenland ice sheet: Nordbogletscher, south Greenland, and Qamanârssûp sermia, West Greenland. The change in summer ablation is nearly linear with change in summer temperature, with gradients of 0.43 and $0.57 \mathrm{~m}$ water $\mathrm{a}^{-1} \mathrm{deg}^{-1}$ for Nordbogletscher and Qamanârssûp sermia, respectively. However, the increase in ablation rate must be less in the higher parts of the ice sheet. A future climatic warming will therefore cause a rapid retreat of the icesheet margin and a steeper ice-sheet profile.

\section{INTRODUCTION}

There is great concern that air pollution will lead to warmer climates in the future, i.e. greenhouse warming, with increased melting of glaciers and ice sheets and a resulting rise in world sea level (Hekstra, 1986). The magnitude of the expected sea-level rise is still uncertain (Robin, 1986). As a contribution to this discussion, we estimate the increase in ice ablation with increasing temperature at the margin of the Greenland ice sheet. Estimates of increased melting for the higher parts of the ice sheet, at and above the present equilibrium line, have already been made by Ambach (1985) and Ambach and Kuhn (1989).

\section{APPROACH}

The basic approach to forecasting ablation under a greenhouse climate is to develop ablation-climate models which describe ablation under present conditions, and then to use them to calculate ablation under changed climate conditions. It is tempting to use simple ablation-temperature correlations for these calculations, cf. Braithwaite and Olesen (1989), but this is questionable a priori because (1) future climates may involve changes in several climatic elements and not just temperature, and (2) the parameters of the ablation-temperature correlation need not be the

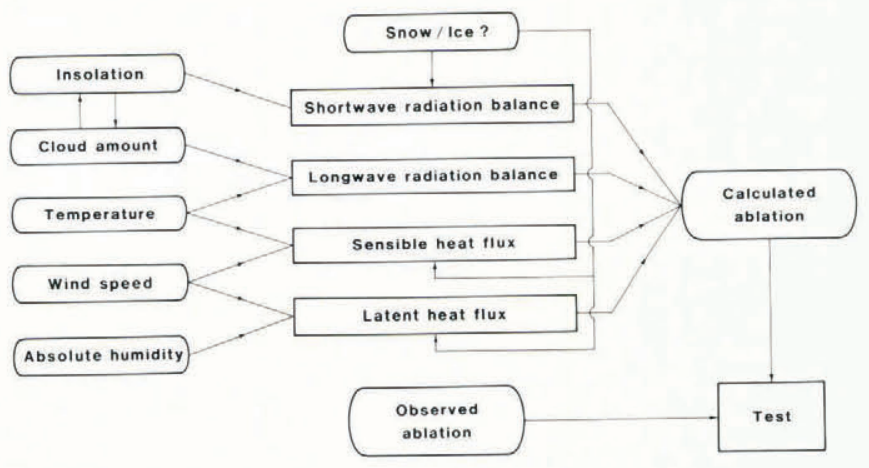

Fig. 1. The calculation of ablation by the simple energybalance model. same under future climates as under present climate. We avoid these problems in the present paper by calculating summer ablation from a simple energy-balance model, using observed data for air temperature, wind speed, humidity, shortwave radiation (insolation) and cloud amount (Fig. 1).

\section{DATA}

Near-daily ice-ablation data and daily climate observations were originally collected on two outlet glaciers for planning hydropower projects (Olesen and Braithwaite, 1989). The ablation is measured at stake 53 ( $880 \mathrm{~m}$ a.s.l.; $61^{\circ} 28^{\prime} \mathrm{N}$ ) on Nordbogletscher, and stake 751 (790 m a.s.1.; $64^{\circ} 28^{\prime} \mathrm{N}$ ) on Qamanârssûp sermia (Fig. 2). The climate data, observed at nearby base camps, comprise daily means of air temperature, humidity and wind speed, and daily totals of precipitation, sunshine duration and insolation. The measurements cover the June-August period for five summers at Nordbogletscher (1979-83) and seven summers at Qamanârssûp sermia (1980-86).

\section{ENERGY BALANCE}

Daily ablation $\mathrm{ABL}^{*}$ is calculated from the energybalance equation:

$$
\mathrm{ABL}^{*}=\mathrm{SHF}+\mathrm{LHF}+\mathrm{SWR}+\mathrm{LWR}
$$

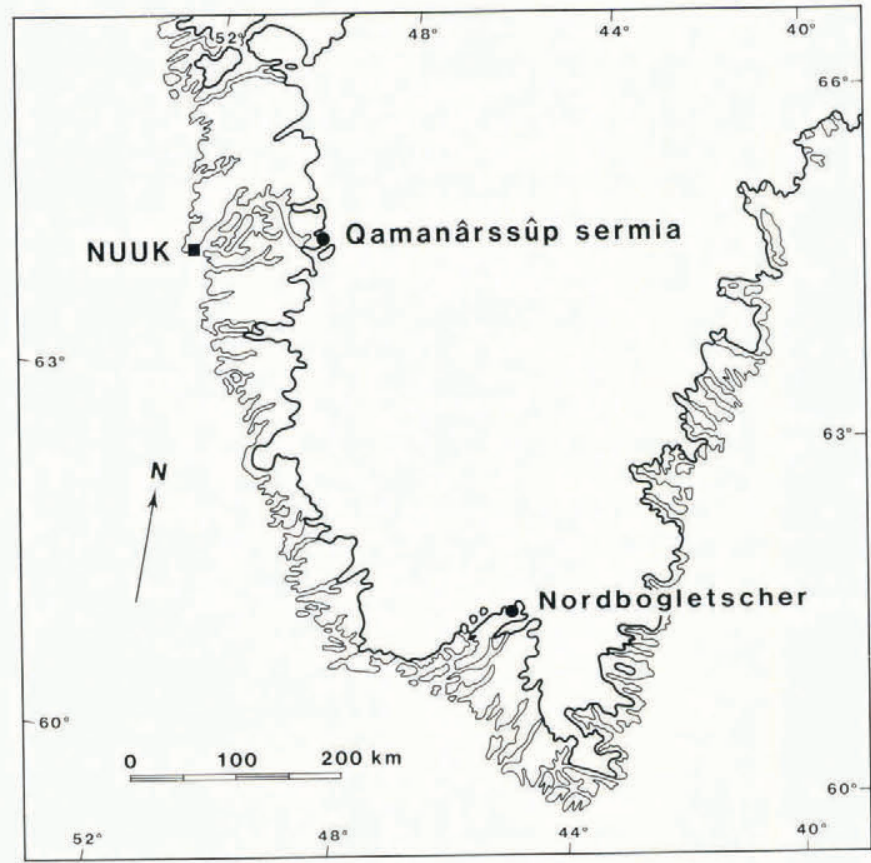

Fig. 2. Two glacier-climate stations of the Geological Survey of Greenland (GGU). 
where SHF and LHF are turbulent sensible and latent heat fluxes, and SWR and LWR are the shortwave and longwave radiation fluxes. Heat conduction into the glacier surface and the specific heat of rainfall are neglected compared with the above terms. For convenience, all balance terms are expressed in ablation units, i.e. as $\mathrm{mm}$ water $\mathrm{d}^{-1}$ or as $\mathrm{kg} \mathrm{m}^{-2} \mathrm{~d}^{-1}$.

Following Ambach (1986), the turbulent heat fluxes are calculated by:

$$
\mathrm{SHF}=K_{\mathrm{S}} \cdot P \cdot T \cdot V
$$

and:

$$
\mathrm{LHF}=K_{\mathrm{L}} \cdot \Delta e \cdot V
$$

where $K_{\mathrm{S}}$ and $K_{\mathrm{L}}$ are coefficients, $P$ is atmospheric pressure (assumed constant for any site), $T$ is screen-level air temperature, $V$ is wind speed, and $\Delta e$ is the difference between the vapour pressure of the air and the saturation vapour pressure at the glacier surface. Equations (2) and (3) are valid for a melting glacier surface and assume a Prandtltype boundary layer. The $K_{\mathrm{S}}$ and $K_{\mathrm{L}}$ parameters incorporate various constants like the specific heat of air, density of air, von Karmen's constant as well as surface roughness parameters. Ambach (1986) gives different values of $K_{\mathrm{S}}$ and $K_{\mathrm{L}}$ for ice and snow surfaces to take account of differences in surface roughness.

The shortwave radiation flux in $m m$ water $\mathrm{d}^{-1}$ is:

$$
\text { SWR }=(1-\alpha) \cdot G / 0.335
$$

where $\alpha$ is the albedo, $G$ is the observed insolation in $\mathrm{MJ} \mathrm{m}^{-2} \mathrm{~d}^{-1}$, and 0.335 is the latent heat of fusion in $\mathrm{MJ} \mathrm{kg}^{-1}$. Ambach (1986) assumed albedos of 0.3 and 0.7 , respectively for ice and snow surfaces. The longwave radiation flux in $\mathrm{mm}$ water $\mathrm{d}^{-1}$ is given by:

$$
L W R=\left(L_{\downarrow_{\mathrm{n}}}-27.35\right) / 0.335
$$

where $27.35 \mathrm{MJ} \mathrm{m}^{-2} \mathrm{~d}^{-1}$ is the outgoing longwave radiation from the melting glacier surface. $L_{\downarrow_{n}}$ is the incoming longwave radiation in $\mathrm{MJ} \mathrm{m}^{-2} \mathrm{~d}^{-1}$ which is given by:

$$
L_{\downarrow_{\mathrm{n}}}=\varepsilon^{*} \cdot \sigma \cdot T_{\mathrm{a}}^{4}
$$

where $\varepsilon^{*}$ is the effective emissivity of the cloudy sky, $\sigma$ is the Stefan-Boltzmann constant, and $T_{\mathrm{a}}$ is the screen-level air temperature on the absolute scale. According to Ohmura (1981) the effective emissivity is given by:

$$
\varepsilon^{*}=8.733 \times 10^{-3} \cdot(1+k n) \cdot T_{\mathrm{a}}{ }^{0.788}
$$

where $k$ is a constant (assumed equal to 0.26 here) and $n$ is the amount of cloud cover which is estimated from sunshine duration. Equation (7) is an empirical equation based on measurements from Axel Heiberg Island, N.W.T., Canada, by Ohmura (1981), who suggests that the temperaturedependence accounts for the increase in absolute humidity with temperature.

The field measurements mainly refer to ice ablation as both sites have little or no winter snow, although traces of new snow occur occasionally in cold periods during the summer and are taken into account in the calculation. The formulae for sensible and latent heat fluxes assume a melting glacier surface, but there are days when this is not the case (usually when air temperatures are below zero but occasionally at positive temperatures) and the calculated ablation is then set to zero.

\section{PRESENT ABLATION}

Ablation $\mathrm{ABL}^{*}$ is calculated according to Equation (1) for every day for which climate data are available in JuneAugust at Nordbogletscher and Qamanârssûp sermia. The ice ablation is also measured almost daily at the two sites using ablation stakes drilled into the ice. The observed ablation $\mathrm{ABL}$ is given by:

$$
\mathrm{ABL}=\mathrm{SHF}+\mathrm{LHR}+\mathrm{SWR}+\mathrm{LWR}+\mathrm{ERR}
$$

\section{TABLE I. OBSERVED ABLATION ABL AND CALCULATED ENERGY BALANCE FOR TWO SITES}

\begin{tabular}{|c|c|c|c|}
\hline Ablation & ABL & $28.7 \pm 20.3$ & $41.5 \pm 29.1$ \\
\hline Sensible heat & SHF & $8.3 \pm 9.6$ & $16.0 \pm 13.4$ \\
\hline Latent heat & LHF & $0.6 \pm 4.8$ & $-1.5 \pm 8.9$ \\
\hline $\begin{array}{c}\text { Shortwave } \\
\text { radiation }\end{array}$ & SWR & $28.7 \pm 13.6$ & $33.1 \pm 16.2$ \\
\hline $\begin{array}{l}\text { Longwave } \\
\text { radiation }\end{array}$ & LWR & $-8.3 \pm 6.1$ & $-6.4 \pm 5.8$ \\
\hline Error & ERR & $-0.5 \pm 13.6$ & $0.4 \pm 1$ \\
\hline
\end{tabular}

\section{Nordbogletscher Qamanârssûp sermia Stake 53 \\ Stake 751}

Days

415

512

Units are $\mathrm{mm}$ water $\mathrm{d}^{-1}$

where $E R R=\left(A B L-A B L^{*}\right)$ and accounts for errors in both the data and in the model.

The calculated energy balance is summarized in Table I by means and standard deviations of the various terms for $415 \mathrm{~d}$ in June-August at Nordbogletscher and $512 \mathrm{~d}$ at Qamanârssûp sermia. Although there are substantial errors on a day-to-day basis, represented by standard deviations of \pm 13.6 and $\pm 18.9 \mathrm{~mm}$ water $\mathrm{d}^{-1}$ for ERR, the model is surprisingly accurate for predicting mean ablation.

Under present climate conditions at Nordbogletscher, turbulence (SHF + LHF) accounts for $31 \%$ of mean ablation energy, radiation (SWR + LWR) accounts for $71 \%$, and $-2 \%$ are unexplained (ERR). Corresponding values for Qamanárssûp sermia are 35\% (SHF + LHF), 64\% (SWR + LWR), and $1 \%$ (ERR). The higher ablation rate at Qamanârssûp sermia compared with Nordbogletscher is mainly due to higher sensible heat flux supplemented by higher incoming shortwave radiation.

The ablation and energy balance values in Table I can be regarded as characteristic of present climate conditions for the two sites. Average daily ablation rates of 28.7 and $41.5 \mathrm{~mm}$ water $\mathrm{d}^{-1}$, respectively for June-August (a period of $92 \mathrm{~d}$ ) are equivalent to June-August ablation totals of 2.64 and $3.82 \mathrm{~m}$ water $\mathrm{a}^{-1}$.

\section{FUTURE ABLATION}

Future ablation is simulated by varying the temperature in the energy-balance model. Wind speed and shortwave incoming radiation remain constant while the turbulent fluxes and longwave radiation increase with increasing temperature. For the latent heat calculation, the vapour pressure of air is assumed to increase with temperature such that the relative humidity remains constant. The albedo for ice is used for the calculation of shortwave radiation, and $K_{\mathrm{S}}$ and $K_{\mathrm{L}}$ parameters appropriate for ice ablation are used when calculating the turbulent fluxes according to Equations (2) and (3). The calculation of June-August ablation was repeated at $1 \mathrm{deg}$ temperature intervals for deviations of -5 to +5 deg from present temperatures, i.e. mean June-August temperatures of 3.7 and $5.0 \mathrm{deg}$, respectively at the Nordbogletscher and Qamanârssûp sermia sites; results are shown in Figure 3.

The ablation change is nearly linear with change in temperature, which mainly reflects the rising probability that melting temperatures occur. The curves for the two sites are not identical but show similar trends, e.g. the June-August ablation at the two sites increases by 0.43 and $0.57 \mathrm{~m}$ water $\mathrm{a}^{-1} \mathrm{deg}^{-1}$, respectively (in the middle of the temperature range). However, in terms of percentage changes of ablation, the two curves are nearly identical, i.e. summer ablation increases by $15 \% \mathrm{deg}^{-1}$ in both cases. This is a hint that 


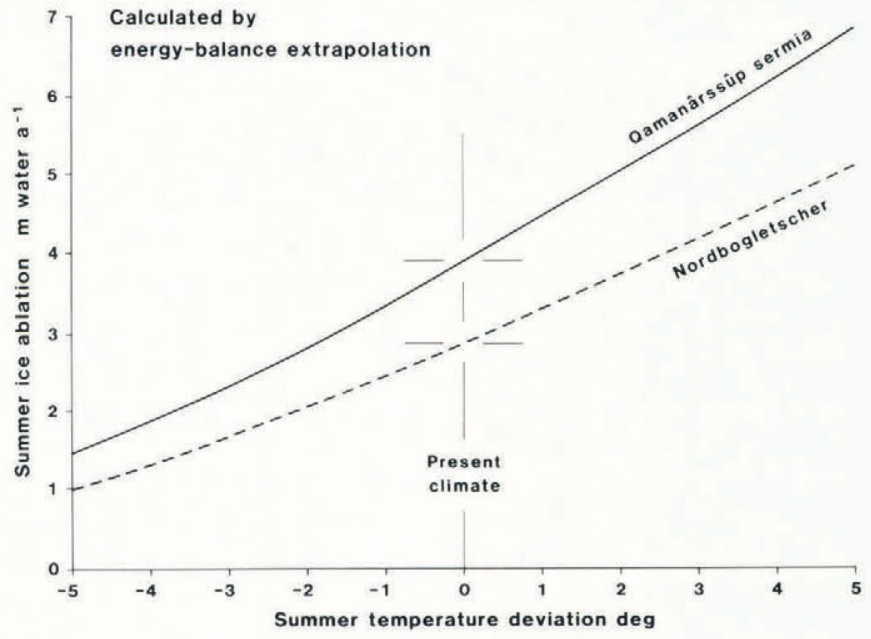

Fig. 3. Calculated summer ice ablation at Nordbogletscher (stake 53) and Qamanârssup sermia (stake 751).

increase in temperature causes ablation to increase in proportion to the existing ablation rate, but no firm conclusion can be based on only two data sets.

\section{DISCUSSION}

A +5 deg temperature rise will cause the June-August ablation to increase by +2.24 and $+2.98 \mathrm{~m}$ water $\mathrm{a}^{-1}$ at Nordbogletscher and Qamanârssûp sermia, respectively, i.e. ablation rate will nearly double. However, the relatively large difference between the two figures shows that the ablation-temperature response is not uniform at the ice margin. Furthermore, the ablation-temperature increase for snow-covered areas on the higher parts of the ice sheet must be much lower than for the ice margin because (1) the melt rate of snow is less than the melt rate of ice at the same temperature (Braithwaite and Olesen, 1988) and (2) at least some of the resulting melt water from snow refreezes within or under the snow cover as ice lenses or superimposed ice, respectively. In particular, there is an extensive refreezing zone above the present firn line where ablation and run-off are essentially zero under present climate conditions. Ablation in this zone will remain zero, despite increased melting, until the refreezing capacity of the snow cover is exhausted, after which run-off will occur.

A future climatic warming is therefore expected to involve a large increase in ablation at the ice-sheet margin and a lesser increase on higher parts of the ice sheet. This will cause a rapid retreat of the ice margin and a steeper ice-sheet profile. The abrupt warming at the termination of the Younger Dryas (Dansgaard and others, 1989) presumably caused a similar large increase in ablation rate.

About half of the present volumetric ablation of the Greenland ice sheet is due to iceberg calving, which occurs in a few fast moving sectors. The dynamics of calving glaciers are still not well understood, but increased temperature will not necessarily increase mass loss in such sectors as higher melting will tend to be offset by the reduction in the ice mass available for calving.

Ablation changes expressed in $\mathrm{m}$ water $\mathrm{a}^{-1}$ can be converted into equivalent changes of sea level by multiplying them by the area of the ablation zone and then dividing by the total area of oceans $\left(360 \times 10^{6} \mathrm{~km}^{2}\right)$. For a first rough calculation, e.g. neglecting the increase in ablation area due to the greenhouse effect, an ablation area of $0.29 \times 10^{6} \mathrm{~km}^{2}$ is assumed (Bauer, 1955). Ablation increases of +2.24 to $+2.98 \mathrm{~m}$ water $\mathrm{a}^{-1}$ for $\mathrm{a}+5 \mathrm{deg}$ temperature rise will be equivalent to sea-level rises of $0.18-0.24$ m $^{2}$ century ${ }^{-1}$.

The above calculation should be treated as a first guess only as ablation rates at both Nordbogletscher and Qamanârssûp sermia must be higher than the average for the whole ice sheet. On the other hand, the present calculations refer only to increases in June-August ablation while warmer temperatures will also cause increased ablation in the September-May period, for which energy-balance calculations are not available.

\section{OUTLOOK}

The extrapolations made here assume that future climate changes will involve uniform changes of summer temperature. This is not necessarily true for the greenhouse effect as climate simulations suggest that winter temperatures will rise more than summer temperatures. Although the energy-balance method can be applied in principle to almost any choice of climate change indicated by climate modellers, the data needed for the energy-balance calculation will not always be available. Experiments are therefore being made to compare results of energy-balance calculations with those obtained with simpler degree-day models involving only air temperatures.

The curves in Figure 3, referring to the ice-sheet margin, represent the higher part of a spectrum of ablationtemperature curves for different conditions, e.g. ice-sheet margin, refreezing zone, and calving sectors. Future work in Greenland should study ablation-climate relations under a range of different conditions and should try to extend local knowledge to the whole ice sheet.

\section{ACKNOWLEDGEMENTS}

This paper is published by permission of the Geological Survey of Greenland. Field work at Nordbogletscher was supported by the European Economic Community (EEC) and the Danish Energy Ministry while the work at Qamanârssûp sermia was wholly funded by the Geological Survey of Greenland.

\section{REFERENCES}

Ambach, W. 1985. Climatic shift of the equilibrium line: Kuhn's concept applied to the Greenland ice cap. Ann. Glaciol., 6, 76-78.

Ambach, W. 1986. Nomographs for the determination of meltwater from snow- and ice surfaces. Ber. Natunwin. Med. Vereins Innsbruck, 73, 7-15.

Ambach, W. and M. Kuhn.. 1989. Altitudinal shift of the equilibrium line in Greenland calculated from heat balance characteristics. In Oerlemans, J., ed. Glacier fluctuations and climatic change. Dordrecht, Kluwer Academic Publishers, 281-288.

Bauer, A. 1955. The balance of the Greenland ice sheet. $J$. Glaciol., 2(17), 456-462.

Braithwaite, R.J. and O.B. Olesen. 1988. Winter accumulation reduces summer ablation on Nordbogletscher, south Greenland. Z. Gletscherkd. Glazialgeol., 24(1), 21-30.

Braithwaite, R.J. and O.B. Olesen. 1989. Calculation of glacier ablation from air temperature, West Greenland. In Oerlemans, J., ed. Glacier fluctuations and climatic change. Dordrecht, Kluwer Academic Publishers, 219-233.

Dansgaard, W., J.W.C. White, and S.J. Johnsen. 1989. The abrupt termination of the Younger Dryas climate event. Nature, 339(6225), 532-534.

Hekstra, G.P. 1986. Will climatic changes flood the Netherlands? Effects on agriculture, land use and well-being. Ambio, 15(6), 316-326.

Ohmura, A. 1981. Climate and energy balance on Arctic tundra, Axel Heiberg Island, Canadian Arctic Archipelago, spring and summer 1969, 1970 and 1972. Zürcher Geogr. Schr, 3.

Olesen, O.B. and R.J. Braithwaite. 1989. Field stations for glacier-climate research, West Greenland. In Oerlemans, J., ed. Glacier fluctuations and climatic change. Dordrecht, Kluwer Academic Publishers, 207-218.

Robin, G. de Q. 1986. Changing the sea level; projecting the rise in sea level caused by warming of the atmosphere. In Bolin, B., B.R. Döös, J. Jäger, and R.A. Warrick, eds, The greenhouse effect, climatic change, and ecosystems. Chichester, etc., John Wiley and Sons, 323-359. 